University of Nebraska - Lincoln

DigitalCommons@University of Nebraska - Lincoln

Forage Nutritional Quality Evaluation of Bahiagrass Selections during Autumn in Florida

\author{
Robert Myer \\ University of Florida, bmyer@ufl.edu \\ Ann Blount \\ University of Florida \\ Samuel Coleman \\ United States Department of Agriculture \\ Jeffery Carter \\ University of Florida
}

Follow this and additional works at: https://digitalcommons.unl.edu/usdaarsfacpub

Part of the Agricultural Science Commons

\begin{abstract}
Myer, Robert; Blount, Ann; Coleman, Samuel; and Carter, Jeffery, "Forage Nutritional Quality Evaluation of Bahiagrass Selections during Autumn in Florida" (2011). Publications from USDA-ARS / UNL Faculty. 525. https://digitalcommons.unl.edu/usdaarsfacpub/525
\end{abstract}

This Article is brought to you for free and open access by the U.S. Department of Agriculture: Agricultural Research Service, Lincoln, Nebraska at DigitalCommons@University of Nebraska - Lincoln. It has been accepted for inclusion in Publications from USDA-ARS / UNL Faculty by an authorized administrator of DigitalCommons@University of Nebraska - Lincoln. 


\title{
Forage Nutritional Quality Evaluation of Bahiagrass Selections during Autumn in Florida
}

\author{
ROBERT MYER, ${ }^{1}$ ANN BLOUNT, ${ }^{1}$ SAMUEL COLEMAN, ${ }^{2}$ \\ AND JEFFERY CARTER ${ }^{1}$ \\ ${ }^{1}$ University of Florida, North Florida Research and Education Center, Marianna, \\ Florida, USA \\ ${ }^{2}$ U.S. Department of Agriculture, Agricultural Research Service, Subtropical \\ Research Station, Brooksville, Florida, USA
}

\begin{abstract}
Bahiagrass (Paspalum notatum Flugge) is the major pasture forage in the southern Gulf Coast, USA. A bahiagrass selection breeding program has been ongoing since 1960 at the Coastal Plain Experiment Station at Tifton, Georgia, USA, to increase forage yield in Pensacola (P. notatum var. sanese) bahiagrass. However, the impact of selecting for forage yield on forage nutritional quality is unknown. Forage quality was evaluated on four Pensacola derived selection cycles (C) of bahiagrass [CO (Pensacola), C4, C9 (Tifton 9), and C23]. A total of 175 plants per cycle were grown. Forage from individual 1-year-old plants was harvested by hand on 3 October and again on 15 November 2000. The samples were dried, ground, and analyzed using internally calibrated near-infrared reflectance spectroscopy (NIRS) for dry matter (DM), in vitro-digestible organic matter $(I V D O M)$, neutral detergent fiber (NDF), and crude protein $(C P)$. Cycle means $\left(\mathrm{g} \mathrm{kg}^{-1}\right.$ DM basis combined over both harvest dates) for IVDOM, NDF, and CP were 497, 810, and 142; 503, 797, and 137; 528, 787, and 132; and 520, 785, and 129 for CO, C4, C9, and $C 23$, respectively. The average IVDOM of $C 4$ was greater than for $C O(P=0.03)$ and that for $C 9$ was greater than for $C 4(P<0.001)$. Results indicated that forage quality also increased with advancing selection cycles for increasing yield.
\end{abstract}

Keywords Bahiagrass, composition, forage, Paspalum notatum, quality

\section{Introduction}

Bahiagrass (Paspalum notatum Flugge) is the major pasture forage in Florida and throughout the southern Gulf Coast region of the United States, in particular for beef cattle production (Gates, Mislevy, and Martin 2001). As a $\mathrm{C}_{4}$ tropical grass, its forage nutritional quality is lower than usually noted for $\mathrm{C}_{3}$ temperate grasses at comparable stages of growth and development (Minson 1980). Typically, bahiagrass lacks the nutritional quality for good animal performance for many classes of livestock with high nutrient demand, but it is persistent, productive with low inputs under hot and humid conditions, and well suited for cow-calf operations (Ball, Hoveland, and Lacefield 1998; Coleman, Moore, and Wilson 2004).

Received 28 April 2009; accepted 9 August 2009.

Florida Agriculture Experiment Station journal series publication.

Address correspondence to Robert Myer, University of Florida, North Florida Research and Education Center, Marianna, FL 34601. E-mail: bmyer@ufl.edu 
Burton (1974, 1982) developed and used restricted recurrent phenotypic selection (RRPS) breeding procedure to improve bahiagrass forage yield. Starting in 1960, Burton selected plants annually for 24 years using this procedure, which resulted in morphology of the plants toward a more upright growth habit (Werner and Burton 1991). Whether forage nutritional quality was improved is not known. Thus, the objective of this research was to evaluate nutritional quality of bahiagrass selections from four Pensacola derived RRPS selection cycles.

\section{Materials and Methods}

Seeds from four RRPS selection cycles (C) of bahiagrass [C0 (Pensacola), C4, C9 (Tifton 9), and C23] were obtained from G. W. Burton, U.S Department of Agriculture, Agricultural Research Service (USDA-ARS), Coastal Plain Experiment Station, Tifton, Georgia, and used in this study. From this seed supply, a total of 175 plants of each cycle were grown in a greenhouse and then transplanted during July 1999 to a 0.2-ha field at the North Florida Research and Education Center near Quincy, Florida ( $30.3^{\circ} \mathrm{N}$ lat.). The soil type was a Norfolk sandy loam (fine-loamy, siliceous, thermic Typic Paleudult). Prior to transplanting, the field was fumigated with methyl-bromide at of $39.2 \mathrm{~g} \mathrm{~m}^{-2}(90 \%$ methylbromide / $2 \%$ chloropicrin). The field was fertilized with 10-0-10 ratio of nitrogen (N) / phosphorus pentoxide $\left(\mathrm{P}_{2} \mathrm{O}_{5}\right)$ / dipotassium oxide $\left(\mathrm{K}_{2} \mathrm{O}\right)$ with added microelements at a rate of $450 \mathrm{~kg} \mathrm{ha}^{-1}$. The plants were planted $0.6 \mathrm{~m}$ apart in rows of 50 plants of a cycle. Because 175 plants of each cycle were planted, there were two rows that contained 25 plants of one cycle and 25 of another. The rows were spaced $0.6 \mathrm{~m}$ apart in a completely randomized design.

Beginning in September 1999, foliage was harvested $10 \mathrm{~cm}$ above the crown of the individual plants by hand clipping every 6 to 8 weeks; foliage was discarded. On 15 August 2000, all plant crowns were hand trimmed to $10 \mathrm{~cm}$ in diameter, and foliage was hand cut to $10 \mathrm{~cm}$ high and discarded. After each harvest, the field was fertilized with 10-10-10 with added microelements at a rate of $560 \mathrm{~kg} \mathrm{ha}^{-1}$. On 3 October and again on 15 November 2000 , foliage growth of individual plants was cut by hand to a height of $10 \mathrm{~cm}$. Foliage was dried at $49^{\circ} \mathrm{C}$ for 3 days and weighed. In all, an average of 164 forage samples per cycle (range of 154 to 174) was obtained from each harvest. Forage was not obtained from all 175 plants because of some plant attrition or plants not having sufficient forage.

The dried forage samples from each plant were ground using a Wiley mill to pass through a 2-mm screen and scanned using a diffuse near-infrared reflectance spectrophotometer (NIRS; NIRSystems model 6500, Silver Springs, Md., USA). Reflected spectral energy was recorded from 400 to $2500 \mathrm{~nm}$ at 2-nm intervals and stored. Variation among spectral data was used to construct principal components that were then used to select representative samples $(n=275)$ from neighborhoods in $n$-dimensional space using the standardized Mahalabanosis distance from the mean (Shenk and Westerhaus 1991a). The SELECT option from InfaSoft International (ISI, State College, Penn., USA) was used for selection. The selected reference samples were analyzed for dry matter (DM) by drying the sample for $15 \mathrm{~h}$ at $105^{\circ} \mathrm{C}$, organic matter (OM) by ashing for at least $4 \mathrm{~h}$ at $500{ }^{\circ} \mathrm{C}$, crude protein $(\mathrm{CP})$ by modified Kjeldahl method using an Alpkem auto-analyzer for color determination (Alpkem Corp., Clackamus, Ore., USA) as described by Noel and Hambleton (1976), neutral detergent fiber (NDF; ash free) using the Ankom A200 filter bag technique (Ankom Technology, Macedon, NY, USA; amylase was used), and in vitro digestible organic matter (IVDOM) according to a modification of the two-stage Tilley and Terry (1963) technique by Moore and Mott (1974). 
Table 1

NIRS calibration statistics for nutritional components of samples selected for reference $(\mathrm{n}=275)$

\begin{tabular}{lccccc}
\hline Item & No. of outliers & Mean $\left(\mathrm{g} \mathrm{kg}^{-1}\right)$ & $\mathrm{SD}^{a}\left(\mathrm{~g} \mathrm{~kg}^{-1}\right)$ & $\mathrm{SECV}^{b}\left(\mathrm{~g} \mathrm{~kg}^{-1}\right)$ & $\mathrm{r}^{2}$ \\
\hline Dry matter & 6 & 901 & 8 & 5 & 0.55 \\
Organic matter & 9 & 910 & 30 & 18 & 0.61 \\
Crude protein & 8 & 133 & 29 & 10 & 0.89 \\
$\mathrm{NDF}^{c}$ & 11 & 741 & 46 & 26 & 0.69 \\
$\mathrm{IVDOM}^{d}$ & 2 & 508 & 47 & 32 & 0.56 \\
\hline
\end{tabular}

${ }^{a}$ Standard deviation for the reference data set.

${ }^{b}$ Standard error of cross validation.

${ }^{c}$ Neutral detergent fiber.

${ }^{d}$ In vitro digestible organic matter.

Reference laboratory data were matched with spectral data, and prediction equations were developed using partial least squares procedures (Shenk and Westerhaus 1991b). The statistical parameters for equations are shown in Table 1. Nutritional values for all samples (including reference samples) were then predicted using the stored spectral data and the prediction equations.

Data were analyzed using the General Linear Model procedure of SAS (SAS Institute 2002). The model included harvest date and cycle. The individual plant was the experimental unit. Significant effects were separated using LSMEANS comparison with the PDIFF option (SAS Institute 2002).

\section{Results and Discussion}

Calibration statistics for compositional components of bahiagrass samples selected for reference for NIRS is presented in Table 1. High ash and small sample set standard deviation caused most $r^{2}$ to be low, but standard error of validation was within the published ranges for these types of analysis (Norris et al. 1976; Reeves 1994).

Rainfall from August to November was $120 \%$ of the 30-year average. October was $25 \%$ of the average, but September was well above normal at $160 \%$.

Concentrations obtained for NDF and CP for bahiagrass in this study were greater than those reported by the National Research Council (NRC 2000); however, IVDOM values were in the range of values reported previously in Florida (Tiffany et al. 1999; Johnson et al. 2001). Johnson et al. (2001) reported greater NDF concentrations in bahisgrass samples taken in late summer compared to early summer. The bahiagrass plants were well fertilized with $\mathrm{N}$ in the present study, which could explain the high $\mathrm{CP}$ values (Buxton and Mertens 1995; Ball, Hoveland, and Lacefield 1998; Johnson et al. 2001).

October and November samplings were done as opposed to earlier samplings as forage nutritional quality is typically low during autumn for bahiagrass (Sollenberger et al. 1988; Tiffany et al. 1999; Johnson et al. 2001). Additionally, bahiagrass nutritional quality is critical at this time for overwintering beef cows in late pregnancy and early lactation. The calving season in the deep southeastern USA is usually earlier (fall and winter) than in other parts of the USA.

The November harvest samples overall averaged greater $(P<0.01)$ IVDOM $(524$ vs. $\left.501 \mathrm{~g} \mathrm{~kg}^{-1}\right)$ and $\mathrm{CP}\left(146\right.$ vs. $\left.125 \mathrm{~g} \mathrm{~kg}^{-1}\right)$ than the October harvest samples; NDF was similar $\left(P>0.10 ; 800\right.$ vs. $\left.790 \mathrm{~g} \mathrm{~kg}^{-1}\right)$. These differences in nutritional quality were probably a 
Table 2

Composition of bahiagrass cycles during autumn

( $\mathrm{g} / \mathrm{kg}$ dry-matter basis; combined over both harvests)

\begin{tabular}{lllllr}
\hline & \multicolumn{4}{c}{ Selection cycle } \\
\cline { 2 - 5 } Item & C0 & C4 & C9 & C23 & SE $^{a}$ \\
\hline IVDOM $^{b}$ & 497 & 503 & 528 & 520 & 10 \\
NDF $^{c}$ & 810 & 797 & 787 & 785 & 10 \\
Crude protein $^{d}$ & 142 & 137 & 132 & 129 & 9 \\
\hline
\end{tabular}

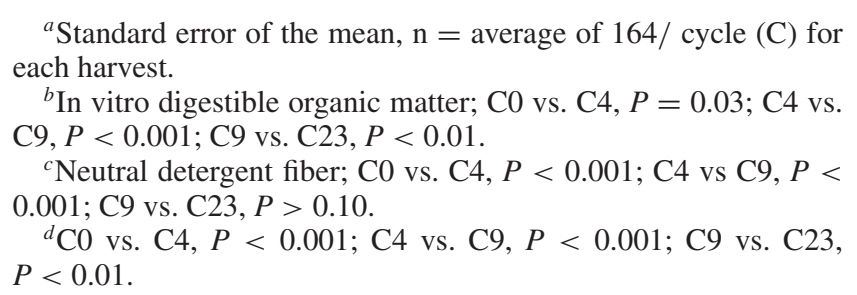

reflection of the cooler weather during the early October to mid-November growth period, compared with mid-August to early October (Buxton and Mertens 1995).

When combined over both harvests, an increase in IVDOM and a decrease in NDF concentrations were noted when going from $\mathrm{C} 0$ to $\mathrm{C} 4(P=0.03$ and $P<0.001$ for IVDOM and NDF, respectively) and again from $\mathrm{C} 4$ to $\mathrm{C} 9(P<0.001$ for all; Table 2$)$. A small decrease $(P<0.01)$ in IVDOM from $C 9$ to $\mathrm{C} 23$ (Table 2$)$ still resulted in the value being greater when compared with $\mathrm{C} 0$ or $\mathrm{C} 4(P<0.01)$. Decreases in $\mathrm{CP}$ were noted for each cycle to cycle for $\mathrm{C} 0$ to $\mathrm{C} 23(P<0.01$; Table 2$)$. There was no harvest date by cycle interaction $(P>0.10)$.

Plant forage yield was also obtained (Blount et al. 2001). As expected, forage yield increased with increasing selection cycle, peaking at C9 (60\% increase vs. C0) with no further increase with $\mathrm{C} 23$. The November harvest overall averaged 6\% less than the October harvest.

From these results, there was evidence that forage nutritional quality did increase with advancing selection cycle. This finding is based on the 5\% increase in IVDOM and the $2 \%$ decrease in NDF as selection cycle increased from $\mathrm{C} 0$ to $\mathrm{C} 23$, in particular from $\mathrm{C} 0$ to $\mathrm{C} 9$. While statistical differences were noted, the actual increases were relatively small. These improvements in quality appeared to peak at C9. Crude protein concentration actually decreased with increasing selection cycle; however, animal nutritionists often place more emphasis on IVDOM and NDF as determinants of forage nutritional quality than CP. Nonetheless, while the bahiagrass RRPS selection goal was to increase forage yield, the results of our study indicated evidence of a concurrent improvement in forage nutritional quality. Intuitively this would be expected as the selection for improved growth and thus yield in bahaigrass would increase the proportion of new tissue growth (Coleman, Moore, and Wilson 2004).

In addition to the quality findings, variation for each parameter within all of the cycles was noted, and this variation was consistent within all the cycles. For example, the variation (one standard deviation) for IVDOM averaged $28 \mathrm{~g} \mathrm{~kg}^{-1}$ (range of 27 to 29). This variation is desirable for plant breeding improvement. Therefore, breeding for improved forage quality within a cycle, as well as across cycles, may be possible. 


\section{Acknowledgment}

The assistance of Harvey Standland, Jeff Jones, Mary Chambliss, and Tina Gwin is gratefully acknowledged.

\section{References}

Ball, D. M., C. S. Hoveland, and G. D. Lacefield. 1998. Southern forages, 2nd ed. Norcross, Ga.: Potash and Phosphate Institute and the Foundation for Agronomic Research.

Blount, A. R., T. R. Sinclair, R. N. Gates, K. H. Quesenberry, and R. C. Littell. 2001. Photoperiod response in Pensacola bahiagrass. In Proceedings of the 29th International Grassland Congress, 10-21. Piracicaba, Sao Paulo, Brazil: International Grasslands Society (paper available at www.internationalgrasslands.org/publications/pdfs/ID 1204-1208.

Burton, G. W. 1974. Recurrent restricted phenotypic selection increases forage yields of Pensacola bahiagrass. Crop Science 14:831-835.

Burton, G. W. 1982. Improved recurrent restricted phenotypic selection increases bahiagrass forage yields. Crop Science 22:1058-1061.

Buxton, D. R., and D. R. Mertens. 1995. Quality-related characteristics of forages. In Forges: The science of grassland agriculture, 5th ed., ed. R. F. Barnes, D. A. Miller, and C. J. Nelson, vol. 5, 83-96. Ames, Iowa: Iowa State University Press.

Coleman, S. W., J. E. Moore, and J. R. Wilson. 2004. Quality and utilization. In Warm-season (C4) grasses, ed. L. E. Moser, B.L. Burson, and L.E. Sollenberger, 267-308. Madison, Wisc.: ASA, CSSA, SSSA.

Gates, R. N., P. Mislevy, and F. G. Martin. 2001. Herbage accumulation of three bahiagrass populations the cool season. Agronomy Journal 93:112-117.

Johnson, C. R., B. A. Reiling, P. Mislevy, and M. B. Hall. 2001. Effects of nitrogen fertilization and harvest date on yield, digestibility, fiber, and protein fractions of tropical grasses. Journal of Animal Science 79:2439-2448.

Minson, D. J. 1980. Nutritional differences between tropical and temperate pastures. In Grazing animals, ed. F. H. W. Morley, 143-157. Amsterdam, the Netherlands: Elsevier Science Publishing.

Moore, J. E., and G. O. Mott. 1974. Recovery of residual organic matter from in vitro digestion of forages. Journal of Dairy Science 57:1258-1259.

Noel, R. J., and L. G. Hambleton. 1976. Collaborative study of a semiautomated method for the determination of crude protein in animal feeds. Journal of the Association of Official Analytical Chemists 59:134-140.

Norris, K. H., R. F. Barnes, J. E. Moore, and J. S. Shenk. 1976. Predicting forage quality by infrared reflectance spectroscopy. Journal of Animal Science 43:889-897.

NRC. 2000. Nutrient requirements of beef cattle, 7th ed. Washington, D.C.: National Academy Press.

Reeves III, J. B. 1994. Near- versus mid-infrared diffuse reflectance spectroscopy for the quantitative determination of the composition of forages and by-products. Journal of Near Infrared Spectroscopy 2:49-57.

SAS. 2002. SAS/C OnlineDOC, ver. 8.2. Cary, N.C.: SAS Institute, Inc.

Shenk, J. S., and M. O. Westerhaus. 1991a. Population definition, sample selection, and calibration procedures for near infrared reflectance spectroscopy. Crop Science 31:469-474.

Shenk, J. S., and M. O. Westerhaus. 1991b. Population structuring of near infrared spectra and modified partial least squares regression. Crop Science 31:1548-1555.

Sollenberger, L. E., W. R. Ocumpaugh, V. P. B. Euclides, J. E. Moore, K. H. Quesenberry, and C. S. Jones Jr. 1988. Animal performance on continuously stocked Pensacola bahiagrass and 'Floralta' limpograss pastures. Journal of Production Agriculture 1:216-220. 
Tiffany, M. E., L. R. McDowell, G. A. O’Connor, F. G. Martin, and N. S. Wilkinson. 1999. Variation of forage and extractable soil minerals over two grazing seasons in north Florida. Communications in Soil Science and Plant Analysis 30:2743-2754.

Tilley, J. M. A., and R. A. Terry. 1963. A two-stage technique for the in vitro digestion of forage crops. Journal of the British Grassland Society 18:104-111.

Werner, B. K., and G. W. Burton. 1991. Recurrent restricted phenotypic selection for yield alters morphology and yield of Pensacola bahiagrass. Crop Science 31:48-50. 